\title{
KOBİ 'lerin Teknoloji Kullanımı Hususunda Yaşadığı İktisadi ve Yönetsel Sorunlar
}

\author{
Fatih Ferhat ÇETINKAYA \\ Kırşehir Ahi Evran Üniversitesi \\ ffcetinkaya40@gmail.com \\ ORCID ID: 0000-0003-2263-0479
}

\begin{tabular}{lrr} 
Araştırma Makalesi & DOI: $10.31592 /$ aeusbed.817822 \\
\hline Geliş Tarihi: 29.10 .2020 & Revize Tarihi: 17.03 .2021 & Kabul Tarihi: 18.03 .2021
\end{tabular}

\section{Atıf Bilgisi}

Çetinkaya, F. F. (2021). KOBİ 'lerin teknoloji kullanımı hususunda yaşadığı iktisadi ve yönetsel sorunlar. Ahi Evran Üniversitesi Sosyal Bilimler Enstitüsü Dergisi, 7(1), 321-340.

\section{ÖZ}

Teknolojinin çok hızlı geliştiği çağımızda, teknolojinin elde edilip kullanılması rekabet avantajı yakalamak için önemli hale gelmiştir. İşletmeler sürdürülebilir rekabet avantajı sağlamak için arayış içerisindedirler. Bu konuda en önemli olan hususlardan bir taneside teknoloji kullanımıdır. Ülke ekonomilerinde önemli yeri olan Küçük ve Orta Büyüklükdeki İşletmelerin (KOBİ) teknoloji kullanımı bakımından araştırma konusu yapılması araştırmanın önemini ortaya koymaktadır. Araştırmanın amacı, KOBİ'lerin teknoloji konusunda yaşadıkları iktisadi ve yönetsel sorunları ortaya koymaktır. Araştırma nitel bir araştırma olup, Kırșehir ilinde faaliyet gösteren $20 \mathrm{KOBİ} \mathrm{üzerinde} \mathrm{yapılmıştır.} \mathrm{Araştırma} \mathrm{verileri} \mathrm{görüşme} \mathrm{yöntemiyle} \mathrm{toplanmış} \mathrm{ve} \mathrm{nitel}$ araştırma yöntemlerinden içerik analizine tabi tutulmuştur. Verilerin kodlanmasında Atlas:ti programı kullanılmıştır. Araştırmanın geçerlilik ve güvenilirlik analizleri yapıldıktan sonra veriler neticesinde bulgular ortaya konulmuştur. Araştırma neticesinde KOBI'lerin, teknoloji kullanımı konusunda ekonomik anlamda sıkıntı yaşadıkları, profesyonel yönetilme konusunda sıkıntı yaşadıkları, Ar-Ge birimlerinin çoğu işletmede olmadığı, verilen teşvikler hakkında yeterince bilgi sahibi olmadıkları ve özellikle teknoloji kullanımı konusunda nitelikli personel bulamadıkları sonuçlarına ulaşılmıștır. Yaşadıkları problemler hakkında çözüm önerileri sunulmuştur.

Anahtar Kelimeler: KOBİ'ler, ekonomi, teknoloji, yönetim.

\section{Economic and Management Problems Experienced by SMEs in Technology Use}

\begin{abstract}
In our age in which technology develops very rapidly, obtaining and using technology has become important to gain competitive advantage. One of the most important issues in this regard is the use of technology. Making a research subject on the use of technology in Small and Medium Business (SMEs), which has an important place in the economies of the country, reveals the importance of the research. The purpose of the research is to reveal the economic and managerial problems SMEs experience in technology. The research is a qualitative research and was conducted on 20 SMEs operating in Kırşehir. The research data were collected by interview method and subjected to content analysis, one of the qualitative research methods. Atlas: ti program was used for coding the data. After the validity and reliability analyzes of the study were made, the findings were presented as a result of the data. As a result of the research, it has been concluded that SMEs have economic difficulties in the use of technology, that they have difficulties in professional management, that R\&D units do not exist in most of the enterprises, that they do not have enough information about the stimulus packaged provided and they cannot find qualified staff especially in technology use. Solution suggestions were presented about the problems they experienced.
\end{abstract}

Keywords: SMEs, economy, technology, management.

\section{Giriș}

Günümüz ekonomik ortamında işletmelerin ayakta kalmaları ve rekabet edebilmeleri serbest piyasa ekonomisinin ve küreselleşmenin de etkisiyle oldukça zor olmaktadır. Ülke ekonomileri bir yana çoğu işletme çokuluslu bir hal alıp dünya pazarını hakimiyetine alma çabası içerisindedir. Gelişmiş ülkelerde büyük işletmelerin yanı sıra KOBI'ler ekonominin lokomotifi durumdadırlar. KOBİ'ler ekonomik açıdan çok önemli olup özellikle istihdama, üretime ve ülke ekonomisine sağladığı katkılar nedeniyle devamlı desteklenmekte ve sayılarının arttırılması amaçlanmaktadır. KOBİ'ler kontrol edilemeyen dış çevre faktörlerine bağlı olarak (teknolojik, ekonomik, hukuki, rekabet ve toplumsal faktörler) ve kendilerinden kaynaklanan nedenlerden dolayı yönetsel, ekonomik ve teknolojik sorunlar yaşayabilmektedirler. 
KOBİ tanımlamalarına bakıldığı zaman değişik ülkelerde ve kurumlarda farklı tanımlamalar yapılmakla birlikte, çalışan kişi sayısının 1-250 arasında olduğu, yıllık net satış miktarı 40 milyon TL'yi geçmeyen işletmeler olarak tanımlanmışlardır (Eğmir ve Hazman, 2017; KOBİ Stratejisi Eylem Planı [KSEP], 2015). KOBİ'ler, dünya ekonomisinin içinde bulunduğu küresel krizlerinde etkisiyle günümüzde çok değişik problemler ile karşılaşabilmektedirler. Teknoloji hızla gelişmekte ve hayatın her alanında yeniliklere yol açmaktadır. Üretim teknolojisi, makine ve teçhizatların yenilenmesi, bilgi ve iletişim teknolojileri, internet teknolojisi, yazılım ve bilişim teknolojisi gibi çoğu alandaki gelişmeler, rekabet ortamında işletmelerin ihtiyaç duyduğu alanlarda teknolojiyi takip etmelerini zorunlu kılmaktadır. Yönetim tarafından planlanması gereken teknolojik yenilikler bazen yöneticilerin bilgi ve yeteneklerine bağlı olarak bazen de ekonomik sebeplerle mümkün olmamaktadır. KOBİ'ler varlıklarını koruyabilmek için çoğu alanda olduğu gibi ekonomik anlamda da bazı sıkıntılarla karşılaşmaktadırlar (Kutlu ve Demirci, 2007).

KOBİ'ler, gelişen teknolojiyi takip ederek ve sürdürülebilir rekabet avantaj1 sağlayabilirler. Teknolojik alt yapının planlanması ve uygulamaya geçirilebilmesi için yönetimin bu konuda gerekli bilgi ve yeteneğe sahip olması gerekmektedir. Bu nedenle yöneticilerin profesyonel olması yada gerekli eğitimi alması yönetsel problemleri azaltacaktır. Teknoloji yatırımları konusunda KOBİ'lerin ihtiyaç duyduğu finansal kaynağa ulaşması ve karşılaştığı ekonomik problemleri çözmesi çok kolay olmamaktadır. Bu nedenle KOBİ'lerin teknoloji konusunda yaşadığı yönetsel ve iktisadi sorunların araştırılması ve çözüm önerilerinin sunulması önem arzetmektedir.

Bu çalışmanın amacı, KOBİ'lerin teknolojiye ulaşabilme ve teknolojiyi kullanma süreçlerini ortaya koymak, teknoloji konusunda yöneticilerin bilgi ve deneyimlerini ölçmeye çalışarak, teknolojik gelişmeleri takip edip edemediklerini tespit etmek ve teknolojiyi elde etme konusunda yaşadıkları ekonomik problemleri ortaya koymaktır. Araştırmada kavramsal olarak çalışma konuları ele alınmış ve açıklanmaya çalışılmıştır. Daha sonra nitel araştırma deseni kullanılarak işletme yöneticilerine çeşitli sorular yöneltilmiş ve alınan cevaplar neticesinde çeşitli durum tespitleri yapılmış ve karşılaşılan problemler ile ilgili çözüm önerileri sunmak amaçlanmıştır.

$\mathrm{Bu}$ araştırmanın amacı doğrultusunda cevap aradığ 1 ana sorusunu: "KOBİ'lerin teknoloji kullanımı konusunda yaşadığı iktisadi ve yönetsel problemleri nelerdir?" ifadesi oluşturmaktadır. Bu bağlamda araştırmanın katılımcılarına araştırmanın amacı doğrultusunda alt araştırma soruları olarak;

- $\quad$ "Firmanızın İçinde Bulunduğu Sorunlardan Bahseder Misiniz? Teknolojik Gelişim Sizin Sorunlarınız Arasında Nerede?"

"Bu Teknolojileri Kullanırken Yaşadığınız Herhangi Bir Problem Var Mı? Ekonomik Problemler Bunun İçerisinde Mi?"

"Üst Yönetimin Teknoloji Kullanımı Konusundaki Çabaları Hakkında Ne Düşünüyorsunuz? Çalışanları Teknolojiye Teşvik Etme Konusunda Neler Yapıyor?” soruları yöneltilmiştir.

\section{KOBİ'lerin Teknoloji Kullanımı ve Yönetsel, İktisadi Sorunları}

KOBİ'ler tanım olarak literatüre bakıldığında nitelik ve nicelik açısından çok değişik şekillerde tanımlanmaktadır. Çalışan personel sayısı, üretim miktarı, yıllık satış miktarı, cirosu gibi çok değişik kriterler ele alınarak KOBİ tanımlarının yapıldığını görmekteyiz (Apan ve İslamoğlu, 2014). KOBİ'ler girişimcilik yeteneklerinin geliştirilmesinde ve yerli teknolojinin geliştirilmesinde motor görevi üstlenirler. Ayrıca kırsal alandan kentlere göçü azaltıp gayrı safi milli hasıla ve ihracata katkıda bulunurlar (Agwu, 2014). Bu önemlerinin yanında KOBİ'ler hızla değişen rekabet ortamında, finansal, yönetimsel, nitelikli personel ve pazar sorunları gibi nedenlerle ciddi sıkıntılar yaşamaktadırlar (Şahin ve Özüdoğru, 2019). Teknoloji kavramı yeni şeyler bulup geliştirmek için üretim esnasında ve iş yapma süreçlerinin tümünde, iletişimde, pazarlamada ve satış ve satış sonrası hizmet sürecinde verimliliği artırmak ve iyileştirmek için yapılan çalışmaların, sahip olunan bilgi becerilerin tümü olarak ifade edilebilir (Şenel ve Gençoğlu, 2003). Teknoloji kavramı hem ürün hemde süreçle ilgili bir kavramdır. Üründe yapılan yeniliklerin yanında üretim sürecindeki 
destekleyici faaliyetlerdeki yenilikleride içerir (Tekin, Güleş ve Öğüt, 2003). Teknoloji üretim esnasında ortaya çıkan ve kullanılan, üretimi kolaylaştıran yeni bilgi ve tecrübeler sonucunda oluşturulan makine, teçhizat ve davranışlar olarak tanımlanabilir (Özdemir, 2010). Teknolojinin özellikle son dönemlerde çok hızlı bir şekilde gelişmesi, Endüstri 4.0 kavramının da hayatımıza girmesiyle üretim, kolaylık, hız, esneklik ve müş̧eri beklentilerini karşılama derecesi gibi konularda ileri teknolojiyi kullanabilen işletmeler avantajlı konuma geçmektedirler. Bu nedenle çevreye uyum sağlamada büyük işletmelere göre daha esnek hareket edebilme kabiliyetine sahip KOBİ'lerinde teknoloji konusunda planlama yapmaları ve gerekli stratejileri belirlemeleri gerekmektedir. KOBİ'ler bunu nitelikli yöneticiler sayesinde gerçekleştirebileceklerdir.

Teknoloji yönetimi; üst yönetimin doğru stratejiler belirleyerek, bilimsel gelişmeleri de dikkate alarak teknik kapasitenin planlanması ve yönetilmesi sürecidir. Teknoloji yönetimi aynı zamanda, işletme amaçlarının gerçekleşmesi için teknoloji planlamasının yapılması, uygulanması ve işletmenin bütün fonksiyonları arasında paylaşılmasıdır (Aydoğan ve Semiz, 2004). İşletmelerde üst yönetimin, teknolojik gelişmeleri takip etmesi, teknolojik liderliği hedeflemesi, bunu yapabilmek içinde gerekli bilgi ve kabiliyete sahip olmaları gerekmektedir. Eğer bu sağlanabilirse işletmeler önemli bir rekabet avantaji elde edeceklerdir (Aydoğan ve Altuğ, 2006). KOBİ'lerin teknolojiyi elde etme ve kullanma konusuna yeterli önem vermedikleri görülmektedir. KOBİ'lerin özellikle bilgi teknolojileri hususunda araştırma geliştirme faaliyetlerine gerekli finansmanı ayırmadıklarını, teknolojik gelişmeleri yeterince takip etmediklerini ve teknoloji için finansmana ve kalifiye elemana ihtiyaç duyduklarını söylemek mümkündür (Yelkikalan ve Ener, 2001). KOBİ’ler yaşadıkları birçok sorunun yanında özellikle sermaye yetersizliğinden kaynaklanan nedenlerle, pazarlamada, reklamda ve özellikle teknoloji alanında çeşitli sıkıntılar yaşamaktadırlar (Turan, 2007). Sakai'ye (2012) göre KOBI'lerin teknolojiyi benimsemesinde etki eden faktörlerin çok daha iyi araştırılması gerekmektedir. KOBI'lerle ilgili yapılan çeşitli araştırmalarda, organizasyon bölümleri arasındaki teknolojik sistemlerin, bilgisayar kullanımının ve elektronik ticaretin kullanılmasını etkileyen çeşitli değişkenler vardır (Ardjouman, 2014). İşletmelerde teknoloji seçimi doğru zamanda yapılmalıdır. Yanlış teknoloji seçimi maliyet kaybına neden olacağından doğru teknoloji seçimi önemli olmakda, teknolojik gelişmelerin çok hızlı olması doğru teknolojiyi seçme konusunda işletmeleri arayışa itmektedir (Gürler ve Güler, 2009).

Ekonomik İşbirliği ve Kalkınma Örgütü (Organization for Economic Cooperation and Development [OECD]) ülkelerine bakıldığında KOBI'lere verilen desteğin büyük çoğunluğu teknolojik yeniliklerle ilgilidir. Bu teknolojik yenilikleri sağlayabilmek için KOBI'ler çeşitli sorunlar yaşamaktadır. Bu sorunlar (Göker, 2001); KOBİ' lerin genellikle girişimcilik, yenilik ve teknoloji konusunda yönetimsel olarak başarısız olmaları, teknolojiyi kendileri üretmek yerine teknoloji transferine mahkum olmaları, çoğu zaman finansman sıkıntısı yaşamaları, KOBİ'lerin kanun ve yönetmeliklere uymakta ve takip etmekte zorluk yaşamaları ve küreselleşme neticesinde uluslararası pazarlara ulaşmada sıkıntı yaşamaları ve fazla bilgi sahibi olmamaları olarak sıralanabilir. Muraya'ya göre (2009) KOBİ'ler teknolojiyi elde etmede ve kullanmada kontrol edilemeyen diş çevre faktörlerinden çok fazla etkilenmektedirler. KOBİ'lerin gerekli teknolojiyi kullanabilmesi için organizasyon özellikleri ve çevre anlamında gerekli şartların oluşması gerekmektedir. Teknoloji kullanımında en önemli dış destek hükümetlerin verdiği destek olup, hükümetlerin gerekli kolaylığı (doğrudan destek ve vergi indirimi) sağlaması gerekmektedir (Ardjouman, 2014). KOBİ'ler kendileri için elzem olan teknolojiyi elde etmek için tabi ki gerekli teşvik ve desteklerin yanında yönetsel ve iktisadi açıdan da çeşitli sorunlar yaşamaktadırlar.

KOBİ'lerin büyük çoğunluğunun aile işletmesi olması nedeniyle üst yönetim aile bireyleri tarafından oluşmaktadır. Günümüz de bilginin, teknolojinin hızla yayılması ve karmaşık rekabet ortamında aile işletmesi sahiplerinin bilgisi ve yeteneği eksik kalabilmektedir. Yine organizasyon yapılarının da hızla değişmesi yeni uzmanlıklar getirmekte ve işletmeler profesyonel yöneticilere ihtiyaç duyabilmektedirler. İşletmelerde karar merciinde olan yöneticilerin profesyonel olmaması ve yetersiz olması firsatların değerlendirilmesi noktasında sorun yaşatabilmektedir (Özgener, 2003). 
KOBİ'lerin günümüz şartlarına uyum sağlamaları ve organizasyon yapılarını buna uygun hale getirmeleri gerekmektedir. Çalışanların fikirlerinin önemsenmesi ve takım çalışmasının olması, esnek bir yapı oluşturulması faydalı olacaktır. Yönetimin, güncel gelişmeleri takip edip gelişmelere uygun kararlarla işletme kaynaklarını etkin kullanacak bilgiye sahip olmaları başarı için önemlidir (Altay ve İlban, 2007). KOBİ'ler yönetsel açıdan bakıldığında, organizasyon yapıları, yönetici yeterlilikleri ve bilgisi bakımından sıkıntılar yaşayabilmektedirler. İşletmelerde karar mekanizmasını oluşturan yöneticilerin, yönetimin temel işlevleri olan; planlama, örgütleme, yöneltme, koordinasyon ve denetim faaliyetlerini layıkıyla yerine getirebilmeleri için küresel ve yerel gelişmeleri takip edebilme ve adapte olabilme yeteneğine sahip olmaları gerekmektedir. Günümüzde teknolojinin çok hızlı gelişmesi üretim, iletişim, pazarlama, dağıtım ve tanıtım gibi işletmelerin temel fonksiyonlarında meydana gelen gelişmeler her alanda uzmanlık bilgisi istemektedir. Teknolojik açıdan yönetimin gelişmeleri takip edebilmesi ve gerekli teknolojiyi elde edebilmesi devamlılık ve rekabet avantaji açısından bir zorunluluktur.

Özellikle ülkemizde KOBI'lerin yaşadığı sorunların en önemlilerinden birisi ekonomik sorunlardır. Türkiye'de KOBI'ler finansmana ulaşmakta sıkıntı çekmekte, faiz oranlarının yüksek olması da finansman problemini etkilemektedir (Türkan, 2011). KOBİ'lerin kaynaklarına bakıldığında özellikle kuruluş aşamasında öz kaynaklar kullanırlar. Genellikle faizli borçlardan kaçınmak için banka kredilerini tercih etmezler. Ama ilerleyen zamanlarda banka kredilerini tercih etmeye başlarlar (Çetin, 2007). KOBI'lerin karşılaştıkları sorunlar sadece sermaye ile ilgili olmayıp, hammaddeye ulaşmakta zorluk, kredilerin yetersiz olması ve döviz kurlarındaki dalgalanmalar gibi sorunlarda olumsuz etki yapmaktadır. Ayrıca çoğu zaman finans danışmanlığı almadıkları içinde yeterli bilgiye ve yeteneğe sahip olamamaktadırlar (Kaygın ve İkinci, 2019). KOBİler sermaye yetersizliğinden genellikle borçlanmak zorunda kalırlar ve çoğu zaman faiz öderler bu durum karlarının azalmasına neden olur. Kendi kendini finanse edebilme yetenekleri büyük işletmelere göre azalır (Çetin, 2007). Rosen'e (2003) göre; özellikle gelişmekte olan ülkelerde özel sektörün girişimcilik faaliyetinde bulunarak istihdama katkısı sağlaması ve kalkınmada rol oynamasının önündeki en büyük engel finansmana erişememesidir (Akderujjaman, 2010). Aras'a (2001) göre KOBİ'lerin ekonomik sorunlarının dört temel nedeni vardır. Bunlar: Ekonomik istikrarsızlık, bankacılık sisteminin yapısal sorunları, teşvik politikalarının yetersizliği, KOBİ'lerin kendi yapılarından kaynaklanan sorunlardır (Kutlu ve Demirci, 2007).

$\mathrm{Bu}$ sorunlara bakıldığı zaman KOBİ'ler, Dünya ve Türkiyede'ki krizlerden çabuk etkilenebilmektedirler. Özellikle gelişmekte olan ülke ekonomilerindeki istikrarsızlıklar KOBİ'leri olumsuz etkilemektedir. Yine bankacilık sisteminden kaynaklanan sorunlar, kredi faizlerinin yüksek olması ve kredilere ulaşmaktaki zorluklar KOBİ'leri olumsuz etkilemektedir. Teşvik politikaları her dönem uygulansa da tamamen yeterli olmayabilmektedir. KOBİ'ler kendi yapılarından kaynaklanan sektörel, teknolojik, yada yönetim gibi nedenlerle de sorun yaşayabilmektedirler.

\section{Kaynak Bağımlılığı Kuramı Çerçevesinde KOBİ'lerin Teknoloji Kullanımı}

Genellikle işletmelerle ilgili teoriler durağan bir yapıya sahip iken kaynak temelli teori dinamik bir yapıya sahiptir. Kaynak temelli teori, dinamik bakış açısıyla işletmelerin devamlı büyüyeceğini ve büyümenin yönetsel bir kalite ve sorumluluk gerektirdiğini savunur. Kaynak temelli teori işletmenin içerisinde bulunduğu endüstriyi de ele alarak, işletmelerin mevcut kaynaklarını etkin kullanarak rekabet avantajı sağlamasını ve buna uygun değerler yaratmasını amaçlar (Akdede ve Turan, 2008). Kaynak Bağımlılık Kuramına göre, işletmeler faaliyetlerini sürdürmek ve bunu nasıl yapmaları gerektiğini araştırmak zorundalardır. Faaliyetlerin sürdürülebilmesi için kaynaklara ihtiyaç vardır ve işletmeler için önemli olan bu kaynaklara sürekli olarak sahip olabilme becerilerinin olmasıdır (Pfeffer ve Salancik, 2003). Kaynak yaklaşımı, işletmelerin sürdürülebilir rekabet avantaj1 sağlayabilmek için varlık ve yeteneklerini kullanmaları gerektiğini savunur. İşletmelerin maddi ve maddi olmayan varlıklarını iyi analiz etmesi ve buna uygun stratejiler geliştirerek rekabet avantajı sağlamanın yollarını araması gerekmektedir (Ülgen ve Mirze, 2010). 
KOBİ'ler kendi imkanlarıyla teknoloji sağlayamazlar ise dışarıdan bu teknolojiyi alacaklar teknolojinin firmaya girmesi gecikecektir. Bu durum KOBI'lerin yeni teknolojiye geçme imkanlarını zorlaştıracaktır. KOBI'ler stratejilerini belirlerken kaynaklarını değerlendirip doğru hamleleri uygulamalıdırlar (Akdede ve Turan, 2008). İşletmelerin rekabet avantaj1 elde etmeleri için, çevresel değişimlere duyarlı olup teknolojik kaynak, yetenek ve becerilerini geliştirmeleri gerekir. Sürekli değişim karşısında işletmeler önlem alıp bu değişime uygun olarak yenilikler yapmalıdır. Kendisinden üstün işletmelerden teknoloji gibi konularda transfer yapmalıdırlar (Öztürk, 2019).

Yapılan literatür incelemesinde konuyla ilişkili olduğu düşünülen bazı araştırma sonuçlarına aşağıda yer verilmiştir.

Gökalp, Ada ve Demirhan (2006) “Gelişen Bilgi Teknolojileri'nin KOBİ'lere Etkisi” adlı çalışmada, yönetim ve planlama gibi konularda yazılım kullanımının yetersiz olduğunu bunun yönetimin eğitim seviyesiyle ilişkili olduğunu, işletmelerin bilgi teknolojilerini kullanmalarının maliyetleri artırdığını, bilgi teknolojileri yatırımlarının maliyetinin yüksekliğini ve nitelikli personel eksikliğini tespit etmişlerdir. Gedik (2017) ise, “Konya Organize Sanayi Bölgesi’ndeki KOBİ'lerin EPazarlama Uygulamaları" adlı çalışmasında; işletmelerin bilgisayar kullandığı ama ileri teknolojiler kullanmadığı, e-pazarlamaya geçiş engelleri ile ilgili önem sırasına göre; nitelikli eleman, teknik bilgi eksikliği, sanal ortamdaki güvenlik sorunu, devlet desteğinin yetersiz olması, tanıtım ve bilgilendirme eksikliği gibi sıkıntılarının olduğunu belirtir. Avşar, Erkek ve Erkek (2018) yaptığı "2005-2015 Yılları Arasında Türkiye'de Uygulanan Ar-Ge ve İnovasyon Politikalarının KOBİ’ler Üzerindeki Etkisi: Konya Tarım Alet ve Makineleri İmalat Sektörü Örneği” adlı çalışmada; işletmelerin çoğunluğu Araştırma ve Geliştirme (Ar-Ge) ve inovasyon teşviklerini yetersiz bulmakta, nitelikli personel sıkıntısı yaşanmakta, işletmelerin bir kısmı rekabette teknolojilerini yeterli görmemekte olduğu sonucuna ulaşmıştır. Varol ve Kaygısız (2018) "KOBI'lerde Teknoloji Kullanımı: Giresun İli Örneği” adlı çalışmada, araştırma kapsamındaki KOBİ'ler, çalışan sayısı ve faaliyet süreleri arttıkça teknoloji kullanım oranlarında ve inovatif çalışmalar gerçekleştirme kapasitelerinin arttığı, üretimde yeni malzeme kullanımından kaçındıkları, bilgi teknolojilerinden yararlanmaya çalıştıkları, işletmelerin tamamının teknolojinin sağlayabileceği faydaların farkında olduklarını fakat nitelikli eleman eksikliği ile karşı karşıya kaldıklarını belirtmişler ve yapılan işlerin teknolojiyi takip ederek yapılması gerektiğini belirtmişlerdir. Marques, Acesto ve Merigo (2015) "Analyzing the effects of technological, organizational and competition factors on web knowledge exchange in SMEs" adlı çalışmasında, teknolojinin KOBI'lerde web bilgi alışverişinde etkili olmadığı, bilgi teknolojisini bilen personelin olmasının internet teknolojilerinde önemli olduğu ve insan kaynaklarının önemli olduğu sonuçlarına ulaşmışlardır. Mittal, Khan, Romero ve Wuest (2018) yaptığı, "A Critical Review of Smart Manufacturing \& Industry 4.0 Maturity Models: Implications for Small and Medium-sized Enterprises (SMEs)" adlı çalışmada; yeni teknolojilerin ve örgüt kültürünün oluşturulması daha fazla kaynak gerektirebilir ve zaman alabilir, endüstri 4.0 bağlamında KOBİ'ler teknolojik gelişmeler için bir danışmana ihtiyaç duyabilir sonuçlarına ulaşmışlardır.

Kaynak bağımlılı̆̆ kuramına dayandırılan bu çalışmada, KOBİ’lerin teknolojiyi kullanma konusunda yönetsel ve iktisadi problemler yaşayabilecekleri düşünülmüştür. Teknoloji çok hızlı bir şekilde geliştiği ve bazen yüksek maliyetlerle elde edilebildiği için, yönetimin bu konudaki bilgi becerisinin ve işletmelerin ekonomik kaynaklarının teknolojiyi elde etmede yeterli olup olmayacağının araştırılmasının önemli olacağı ve literatüre katkı sağlayacağı düşünülmüştür. Nitel araştırma deseniyle elde edilen verilerin daha faydalı olacağı düşüncesiyle çalışmanın yöntem kısmı hazırlanmıştır.

\section{Yöntem}

Araştırmanın yöntem kısmında; araştırmanın deseni, araştırma verilerinin toplanması ve analizi, araştırmanın geçerliliği ve güvenilirliği ve araştırma etiği kısımlarına yer verilmiştir. 


\section{Araștırmanın Deseni}

$\mathrm{Bu}$ araştırma, KOBI'lerin teknoloji kullanımı konusunda yaşadıkları iktisadi ve yönetsel problemlerini ortaya koymak amaciyla yapılmış, nitel yöntemle verilerin toplandığı bir durum çalışmasıdır. Araştırmanın amacı, KOBİ'lerin teknoloji kullanımı hususunda yaşadığı mevcut sorunları ve durumları hakkında görüşme yöntemi ile detaylı ve derinlemesine bilgi toplayarak bir durum betimlemesi yada durum temaları ortaya koyarak (Creswell, 2013), KOBİ'lerin sorunların saptamaktır. Nitel araştırmalar, istatistiki işlemlerin yer verilmeden sonuçlara ulaşıldığı araştırmalardır. Nitel araştırmada kullanılan örneklem üzerinden ana kitle üzerinde genellemeler yapmak amaçlanmaz. Nitel araştırmaların amacı, araştırılan konular ile ilgili verilen cevapların derinlemesine incelenmesidir (Yıldırım ve Şimşek, 2011). Araştırma da öncelikle uzman görüşleri doğrultusunda araştırma soruları formu oluşturulmuştur. Sorular araştırma problemine uygun olarak, işletmelerin teknoloji kullanımında karşılaştıkları iktisadi ve yönetsel sorunları ortaya çıkarmaya yönelik sorulardır. Araştırma verileri görüşme yöntemi ile toplanmıştır.

Araştırma neticesinde elde edilen veriler uygun istatistiksel programda analiz edilerek kategoriler oluşturulmuştur. Daha sonra veriler doğrultusunda içerik analizi yapılmıştır. İçerik analizi, nitel veri analiz türlerinden yaygın olarak kullanılan yöntemlerdendir. İçerik analizinde araştırma konusu ile ilgili kategoriler oluşturularak (Silverman, 2001), araştırma konusu ile ilgili bulunan sonuçlar raporlaştırılır.

\section{Evren ve Örneklem}

Araştırmanın Evrenini Kırşehir ilinde faaliyet gösteren KOBİ'ler oluşturmaktadır. Araştırmanın örneklemini ise Kırşehir ilinde faaliyet gösteren 20 KOBİ oluşturmaktadır. Nitel araştırmalarda 5 ila 20 arasında örneklemin yeterli olabileceği (Creswell, 2013) belirtilmektedir.

\section{Verilerinin Toplanması ve Analizi}

Araştırmanın geçerlilik ve güvenilirliğini test etmek amacıyla nitel araştırma yöntemlerinde kullanılan geçerlilik ve güvenilirlik süreci dikkate alınmıştır. Nitel araştırma yöntemlerinde iç geçerlilik, araştırmanın doğruluğunu ve araştırma bulgularının gerçeği yansıtıp yansıtmadı̆̆ının belirlenmesini, dış geçerlilik ise, benzer örneklemler üzerinde araştırma sonuçlarının genelleştirilip genelleştirilemeyeceğini ortaya koyar (Yıldırım ve Şimşek, 2011). Bu bağlamda araştırmanın geçerliliğini sağlamak için araştırma soruları hazırlanırken alanında uzman iki akademisyenin görüşlerine başvurulmuştur. Araştırmaya farklı özellikteki kişilerin katılımı sağlanarak araştırmanın geçerliliği artırılmaya çalışılmıştır. Veriler toplanırken ses cihazına kaydı yapılmıştır ve araştırmacı tarafsız kalarak geçerlilik artırılmaya çalışılmıştır. Son olarak araştırmanın geçerliliğini artırmak için nitel çalışmalar yapmış bir akademisyenin görüşlerine başvurulmuştur. $\mathrm{Bu}$ anlamda araştırmanın geçerliğinin sağlandığı düşünülmektedir. Araştırmanın güvenilirliğini sağlamak için elde edilen veriler kodlanmış ve bir başka nitel çalışma yapmış akademisyene kodlama yaptırılarak kodlar karşılaştırılmıştır. Kodlamalarda benzerliğin fazla olduğu görülmüştür. Yine araştırmanın güvenilirliğini sağlamak için ses kayıtları dinlenerek verilerle uyumu incelenmiştir. $\mathrm{Bu}$ anlamda araştırmanın güvenilir olduğu söylenebilir.

Araştırmanın verileri görüşme yöntemi ile toplanmıştır. Araştırma verileri toplanırken katılımcılar belirlenmiş ve katılımcılara görüşmenin içeriği ve ayıracakları zaman belirtilmiştir. Görüşmeyi kabul eden 20 katılımcı ile yüz yüze yapılan görüşmeler ile veriler toplanmış aynı zamanda ses kayıtları alınmıştır. Araştırma verilerini analiz etmek için önce veriler anaqliz için düzenlenmiştir. Daha sonra veriler Atlas:ti programına tabi tutularak kodlamalar gerçekleştirilmiştir. Nitel araştırma yöntemlerinden içerik analizi yöntemi ile de bulgular yorumlanarak literatür ile ilişkilendirilme ve karşılaştırmalar yapılmıştır. 


\section{Araştırma Etiği}

Araştırma etiği kapsamında ilk etapta görüşme formları alanında uzman 2 akademisyene sorularak etik olup olmadıkları sorulmuş ve onayları alınmıştır. Daha sonra makale görüşme formları Ahi Evran Üniversitesi Etik Kuruluna başvurularak araştırma sorularının etik olduğuna dair etik kurul onayı alınmıştır.

\section{Bulgular}

Bu bölümde araştırma neticesinde elde edilen veriler ile ulaşılan bulgulara yer verilmiştir.

\section{Araştırmaya Katılanların Demografik Özelliklerine İlişkin Bulgular}

Çalışmanın bu bölümünde araştırmaya katılan KOBİ çalışanlarının demografik özelliklerine ilişkin tanımlayıcı bulgular sunulmuştur.

Tablo 1

Katılımcıların Özelliklerine İlişkin Bulgular

\begin{tabular}{|c|c|c|c|c|}
\hline Katılımcı & Sektör & $\begin{array}{l}\text { Personel } \\
\text { Sayısı }\end{array}$ & $\begin{array}{l}\text { İhracat } \\
\text { Durumu }\end{array}$ & Kuruluş Tarihi \\
\hline $\mathrm{K} 1$ & Otomasyon & 18 & Hayır & $2014\left(6 Y_{11}\right)$ \\
\hline $\mathrm{K} 2$ & Enerji & 60 & Evet & 1987 (33 Y1l) \\
\hline K3 & Petrol İstasyonu & 11 & Hayır & 2009 (11 Yil) \\
\hline $\mathrm{K} 4$ & Lastik Bayiliği & 10 & Hayır & $1998(22$ Y1l) \\
\hline $\mathrm{K} 5$ & Tarım & 15 & Hayır & $2011\left(9 Y_{11}\right)$ \\
\hline K6 & Tarım & 20 & Evet & 2001 (19 Y1l) \\
\hline K7 & Halı, Mobilya & 20 & Hayır & 2003 (17 Y11) \\
\hline K8 & Tarım & 17 & Hayır & 1992 (28 Y11) \\
\hline K9 & Petro- Kimya & 100 & Hayır & $1995\left(25 Y_{11}\right)$ \\
\hline K10 & Tekstil & 135 & Evet & 1993 (27 Y1l) \\
\hline K11 & G1da & 118 & Hayır & 2005 (15 Y1l) \\
\hline K12 & Yemek & 10 & Hayır & $2016\left(4 Y_{11}\right)$ \\
\hline K13 & İnşaat & 17 & Hayır & $1998(22$ Y1l $)$ \\
\hline K14 & Gida Temizlik & 60 & Hayır & $2010(10$ Y1l $)$ \\
\hline K15 & Organizasyon & 36 & Hayır & 2017 (3 Y1l) \\
\hline K16 & Kömür & 10 & Hayır & $2000(20$ Y1l $)$ \\
\hline K17 & Gida ve Hayvancı. & 349 & Evet & 1969 (51 Y1l) \\
\hline K18 & Tekstil & 25 & Hayır & 1995 (25 Y11) \\
\hline K19 & Makina & 150 & Hayır & $1996\left(24 Y_{11}\right)$ \\
\hline K20 & Organizasyon & 15 & Hayır & 2003 (17 Y1l) \\
\hline
\end{tabular}

Tablo'1'de görüldüğü üzere araştırmanın etik ilkeleri açısından katılımcılara isimleri yerine K1, K2 ..... K20 şeklinde isimler verilmiştir. Katılımcıların çalıştıkları sektörlere bakıldığında çoğu katılımcının farklı bir sektörde faaliyet gösterdiği görülmektedir. Katılımcıların personel sayısı ortalamas1 59.8'dir. Kat1lımcılardan 16 (\%80)'i ihracat yapmıyorken, 4 (\%20)'si ihracat yapmaktadır. Katılımcıların sektörde bulunma ortalamaları ise 19.4 yıldır.

\section{Katılımcıların Görüşme Sorularına Verdikleri Cevaplara İlişkin Bulgular}

Çalışmanın bu bölümünde alan araştırması kapsamında katılımcılara yöneltilen sorular ve katılımcıların bu sorulara verdikleri cevaplar ayrıntılı olarak sunulmuştur.

Soru 1: "Sektörünüze İlişkin Teknolojik Gelişmeler Hakkında Ne Düşünüyorsunuz? Firmanızı Bu Teknolojik Gelişmelerin Neresinde Görüyorsunuz?" 
Katılımcıların çoğunluğu soruya, teknolojinin hızla geliştiğini ve imkânları dâhilinde teknolojik gelişmelere ayak uydurduklarını dile getirmişlerdir. Ayrıca katılımcıların bu soruya yönelik verdikleri cevaplar aşağıda sunulmuş̧ur.

Sektörümüzde teknolojik gelişmeler gelişmiş ülkelerin gerisinde kalmaktadır. Firma olarak üretim programlarında Türkiye'de bulunan en son otomasyon sistemlerini kullanmaktayız (K6).

Sürekli yenilenen bir teknoloji sektörü bu yüzden hızl değişimler olmakta. Firmamız değişen teknolojik gelişmelere en üst seviyede ayak uydurmaktadır (K7).

Sektördeki teknolojik gelişmeleri takip ediyoruz. Mevcut durumumuzu iyi görüyoruz (K20).

Soru 2: "Rakipleriniz Bu Teknolojik Gelişmenin Neresinde? Onların Teknolojik Gelişmelerini Nasıl Görüyorsunuz? Rakiplerinizle Firmanızın Teknoloji Düzeylerini Karşılaştırır mısınız?"

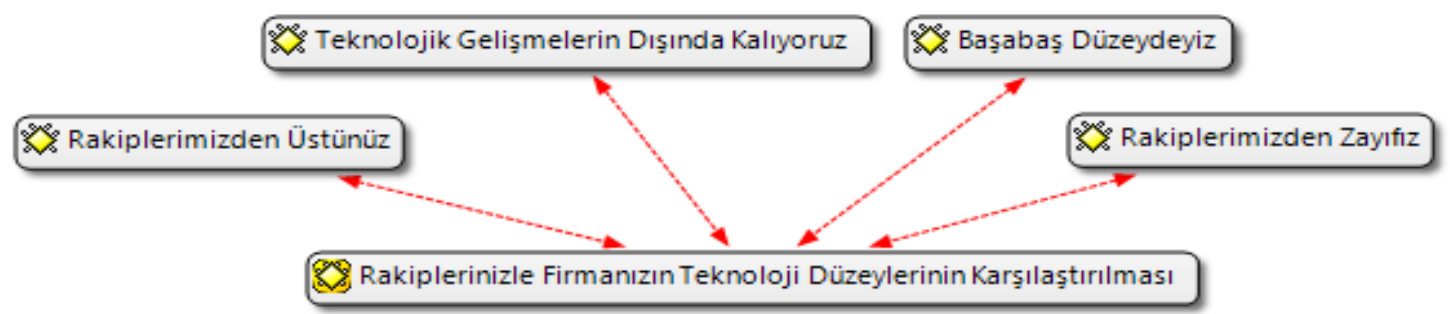

Şekil 1. Katılımcıların Rakipleri İle Kendi Firmalarının Teknoloji Düzeylerinin Karşılaştırmasına Yönelik Verilen Cevaplar

Katılımcılardan 5 kişi $(\mathrm{K} 3, \mathrm{~K} 4, \mathrm{~K} 10, \mathrm{~K} 12, \mathrm{~K} 13)$ kendi firmasını rakiplerinden üstün görüyorken, 2 Kişi (K17, K20) kendi firmasını rakiplerinden zayıf görmektedir. 11 kişi $(\mathrm{K} 1, \mathrm{~K} 2, \mathrm{~K} 6, \mathrm{~K} 7, \mathrm{~K} 8, \mathrm{~K} 9, \mathrm{~K} 11, \mathrm{~K} 14, \mathrm{~K} 15, \mathrm{~K} 18, \mathrm{~K} 19)$ bu konuda rakipleri ile kendi firmalarının başa baş gittiklerini söylemektedir. 2 kişi $(\mathrm{K} 5, \mathrm{~K} 16)$ ise teknolojik gelişmelerin dışında olduklarını ve bu konudan çok fazla etkilenmediklerini ileri sürmektedir.

Rakipleri takip etme konusunda zaylf olduğumuzu düşünüyorum. Fakat zaman zaman internet üzerinden yaptığımız satışlarla rakiplerimize yaklaşıyoruz (K1).

Şuan da opet firmasının bayiliğini sürdürmekteyiz. Bundan dolayı rakiplerimizden teknolojik olarak daha üstün ve yenilik takipçisiyiz. Rakiplerimizin önündeyiz(K3).

Firmamızın piyasa hâkimiyetinin yüksek olmasından ötürü rakiplerden öndeyiz (K13).

Soru 3: "Sizce Teknolojik Gelişmeler Rekabet Gücü ve Eğer İhracat Yapıyorsanız Bunun Üzerinde Etkili Midir? Sizin Firmanız Üzerindeki Etkisini Anlatır Mısınız?" 


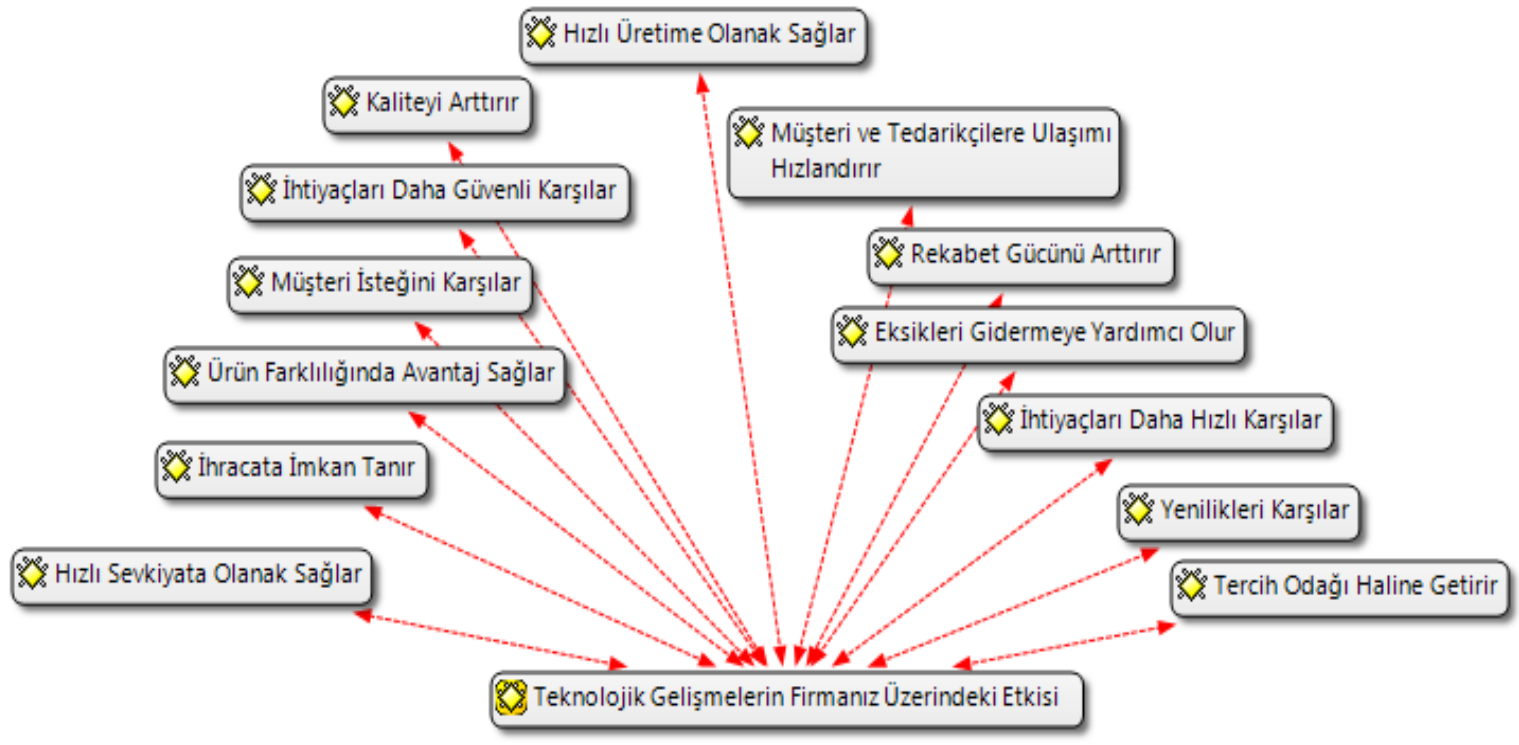

Şekil 2. Teknolojik Gelişmelerin Firmalar Üzerindeki Etkisine Yönelik Verilen Cevaplar

Katılımcıların verdiği cevaplara göre teknolojik gelişmelerin hızlı sevkiyata olanak sağladığı, ihracata imkân tanıdığı, ürün farklılığında avantaj sağladığı, müşteri isteğini karşıladığı, kaliteyi arttırdığı, hızlı üretime olanak sağladığı sonuçlarına ulaşılmıştır.

Tabiki etkisi vardır. Hızlı üretim eşittir hızl sevkiyat demektir. Buda rekabet gücünü artırır. Firmamız olarak sipariş, üretim ve sevkiyat sürecinde son teknolojiler sayesinde çok kısa sürede işlem yapılmaktadir (K6).

Rekabet olmadan sektörel gelişme olmaz. Hizlı ve seri bir üretim için teknoloji şart. Kullandı̆̆ımız teknoloji ile üretim ve verimliliğimizin arttı̆̆ın söyleyebiliriz (K14).

Teknolojik gelişmelerin rekabeti kızıştırdığını ve birçok etkisi olduğunu düşünüyorum. Müşteriyle olan ilişkimizi daha kolay sağlıyor. Yaptığımız yenilikleri daha rahat bir şekilde sunmamiza yardimcı oluyor (K15).

Soru 4: "Firmanızın İçinde Bulunduğu Sorunlardan Bahseder Misiniz? Teknolojik Gelişim Sizin Sorunlarınız Arasında Nerede?”

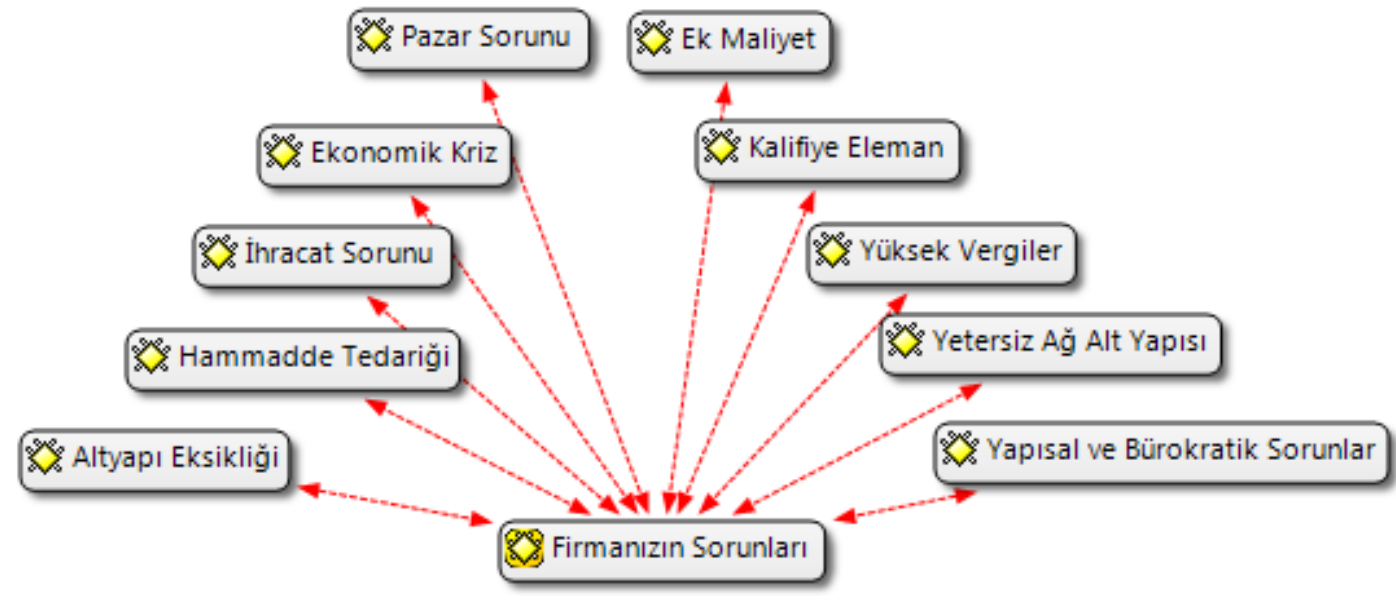

Şekil 3. Katılımcıların Firmalarının Sorunlarına Yönelik Verilen Cevaplar

Katılımcıların verdikleri cevaplara bakıldığında alt yapı eksikliği, hammadde tedariki, ihracat ve pazar sorunu, ekonomik kriz, ek maliyetler, yapısal ve bürokratik sorunlar, yüksek vergiler, kalifiye eleman yetersizliği gibi sorunların teknolojik gelişim sorununun önüne geçtiği görülmektedir. 
Dünyada ve Türkiye'de yaşanan ekonomik kriz en önemli sorunlarımızdan birsidir. İşe uygun personelin bulunması konusunda sıkıntı çekmekteyiz. Teknolojik sorunlar daha sonra gelmekte (K1).

Firmamız nitelikli personel bulmakta sıkıntı çekiyor. Ülkemiz bu konuda yeni adımlar atıyor. Ayrıca altyapı noktasinda da eksiklikler bulunmaktadır (K2).

Personellerin yeterince işlerine sahip çıkmaması ve iyi çalışan insan sayısının az olması (K5).

Teknolojik gelişmeler çok iyi kullanmadığımız için ihracatta zorluklar yaşanıyor (K17).

Sektörde rekabet ön planda, yapısal ve bürokratik sorunlarla karşılaşıyoruz (K18).

\section{Soru 5: "Firmanızın Çalışma Alanlarındaki Yeni Teknolojiler Hakkında Neler Biliyorsunuz? Siz Firma Olarak Bu Teknolojilerden Hangilerine Sahipsiniz?”}

Katılımcılar genellikle birbirlerinden farklı sektörlerde hizmet verdikleri için sahip oldukları teknolojiler hakkında da çeşitli cevaplar vermişlerdir. Katılımcıların bu soruya verdikleri cevaplar aşağıda sunulmuştur.

Firmamız yeni teknolojilere enerji noktasından ihtiyaç duymaktadır. Yeni teknoloji birçok firsatı sunmakta ve bu firsatı rekabete yansitmakta kararlılık gösteriyoruz (K2).

Takip ediyoruz. Teknolojik gelişmelerin uygulandığı ürünleri piyasaya sokuyoruz (K13).

Çalışma alanındaki teknolojinin kullanımı üretim sürecinde daha yaygındır (K14).

Soru 6: "Bu Teknolojileri Kullanırken Yaşadığınız Herhangi Bir Problem Var Mı? Ekonomik Problemler Bunun İçerisinde Mi?”

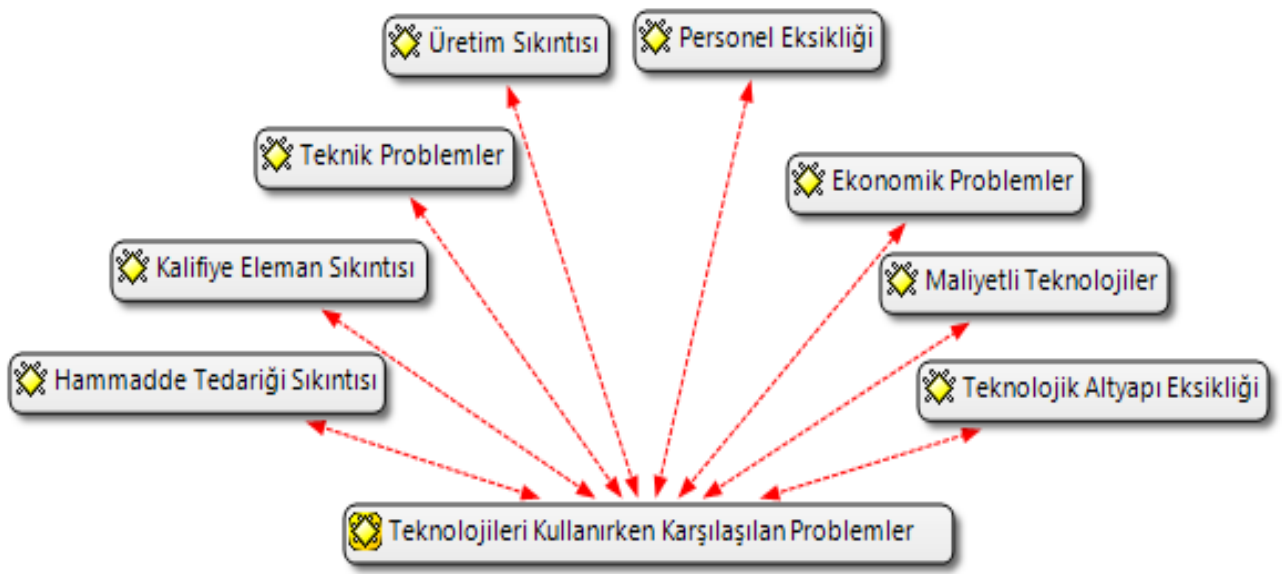

Şekil 4. Katılımcıların Teknolojiyi Kullanırken Karşılaştı̆̆ Problemlere Yönelik Verilen Cevaplar

Katılımcıların hammadde tedariki, kalifiye eleman sıkıntısı, teknik problemler, üretim sıkıntısı, personel eksikliği, ekonomik problemler, maliyetli teknoloji ve teknolojik altyapı eksikliği gibi problemlerle karşılaştıkları görülmüş̧ür. Ayrıca katılımcıların çoğu karşılaştıkları sıkıntıların içerisine ekonomik problemleri de eklemişlerdir.

Zaman zaman problemler yaşamaktayız. Bu konuyla ilgili yaşadı̆̆ımı en önemli problem ekonomiktir. Son zamanlarda yaşanan krizin etkisiyle doların artması bu teknolojilere sahip olmamızın önündeki en büyük sorun (K1).

Genellikle yetişmiş eleman konusunda sıkıntı yaşlyoruz. Ekonomik problem çok yaşamıyoruz ama yaptı̆̆ımız yatırıma gerek var mı onu tam kestiremiyoruz (K10).

Ekonomik problem en önemli husus zaten. Teknoloji ürünlerin maliyeti ve vergileri yüksek. Bunların bakımı da maliyetli, bu konuda kalifiye işçi çalıştırmak zorundayız (K11).

Soru 7: "Teknoloji Kullanımının Teşvik Edilmesi ile İlgili Verilen Teşvikler ile İlgili Neler Biliyorsunuz? Bu Teşvikleri Takip Ediyor Musunuz, Kullanıyor Musunuz?" 


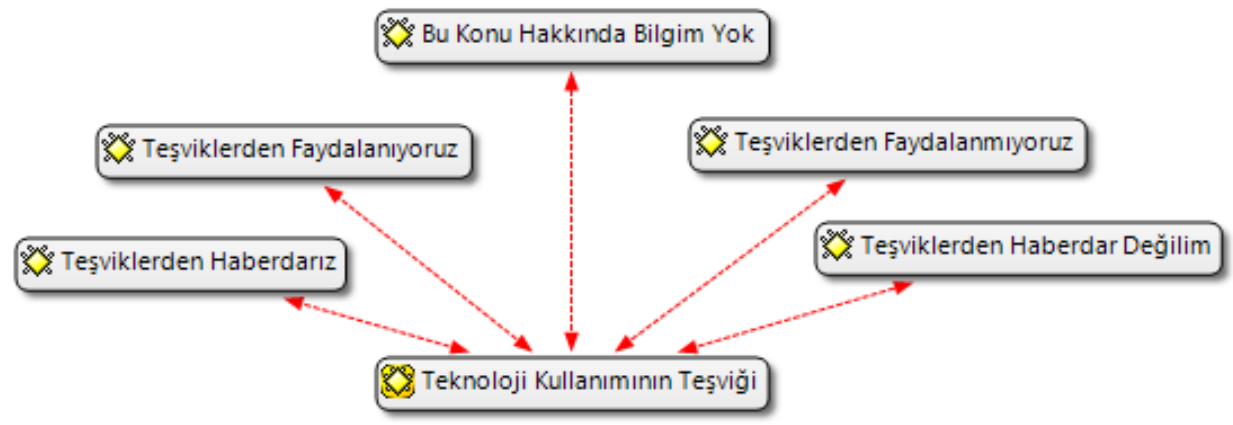

Şekil 5. Teknoloji Kullanımının Teşvik Edilmesine Yönelik Verilen Cevaplar

Katılımcıların bir kısmı teşviklerden haberdar olduklarını söylemiştir, teşviklerden haberdar olan katılımcıların bazıları teşviklerden faydalandıklarını dile getirirken bazıları ise faydalanmadıklarını söylemiştir. Ayrıca katılımcıların bir kısmı teşviklerden haberdar olmadıklarını ve hatta bu konu hakkında hiçbir bilgisinin olmadığını ifade etmiştir.

Teknolojinin kullanımın teşvik edilmesi noktasında Ar-Ge çalışmaları kapsamında TÜBITTAK ile görüssmelerimiz devam ediyor (K2).

Ülkemizde maalesef teknolojik gelişmelerde çok fazla bir destek yok. Bu yüzden yararlanamiyoruz ve takipte edemiyoruz (K3).

Teşvikleri biliyoruz. Fakat makine grubuna hitap ettiği için bizim alanımıza girmiyor (K5).

Soru 8: "Teknolojik Cihazları Kullanabilmek İçin Hangi Özellikte Elemanlara İhtiyaç Vardır? Bu Elemanları Bulma Konusunda Yani Kalifiye Eleman Konusunda Sıkıntı Yaşıyor Musunuz?"

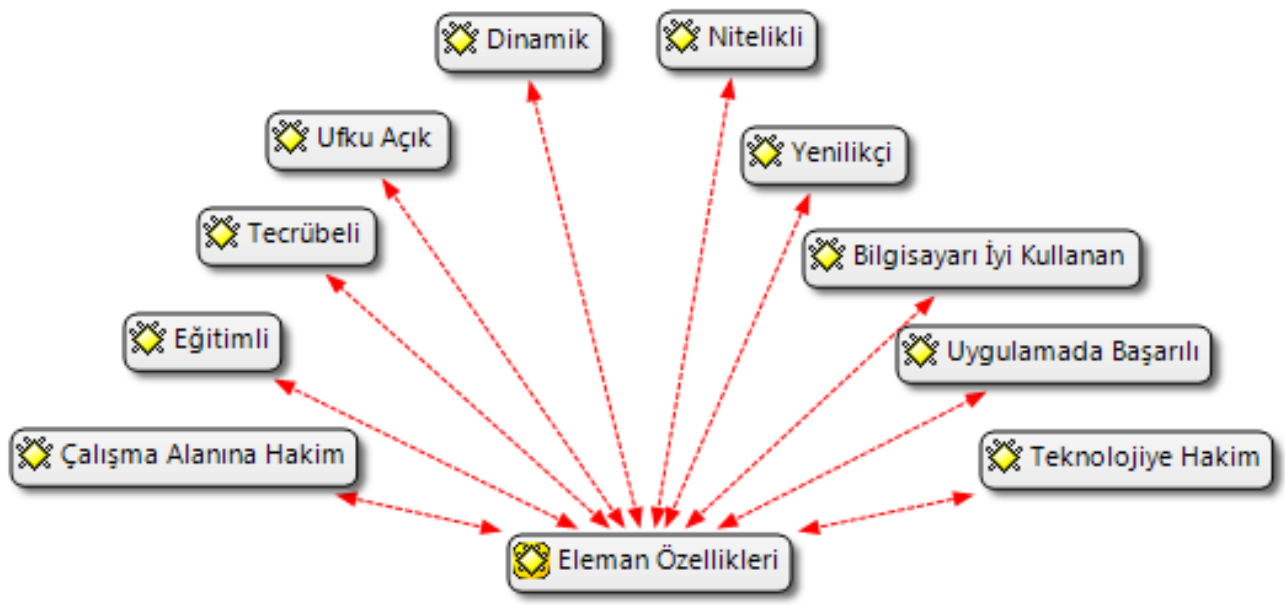

Şekil 6. Teknolojik Cihazları Kullanabilmek İçin Hangi Özelliklere Sahip Elemanlara İhtiyaç Olduğuna Yönelik Verilen Cevaplar

Katılımcıların çoğunluğu kalifiye eleman konusunda sıkıntı yaşadığını belirtirmiştir. Ayrıca teknolojik cihazları kullanabilmek için çalışma alanına hâkim, eğitimli, tecrübeli, ufku açık, dinamik, nitelikli, yenilikçi, bilgisayarı iyi kullanabilen, teknolojiye hâkim, sadece teoride değil aynı zamanda uygulamada da başarılı olabilen elemanlara ihtiyaç olduğunu vurgulamışlardır.

Nitelikli ve ufku açık elemana gereksinim duyulmaktadır. Eğitim noktasında yeni düzenlemeleri takip ederek ihtiyaç duyduğumuz personeli temin etme noktasında çalışlyoruz (K2).

Kldemli personel ve teknolojiyi iyi takip eden, kullanan elemanlara ihtiyaç duyuyoruz. Ama bu konuda yeterli eleman bulamadiğımız için kendi imkanlarımızla kurslara gönderiyoruz (K17). 
Soru 9: "Üst Yönetimin Teknoloji Kullanımı Konusunda Çabaları Hakkında Ne Düşünüyorsunuz? Çalışanları Teknolojiye Teşvik Etme Konusunda Neler Yapılıyor?”

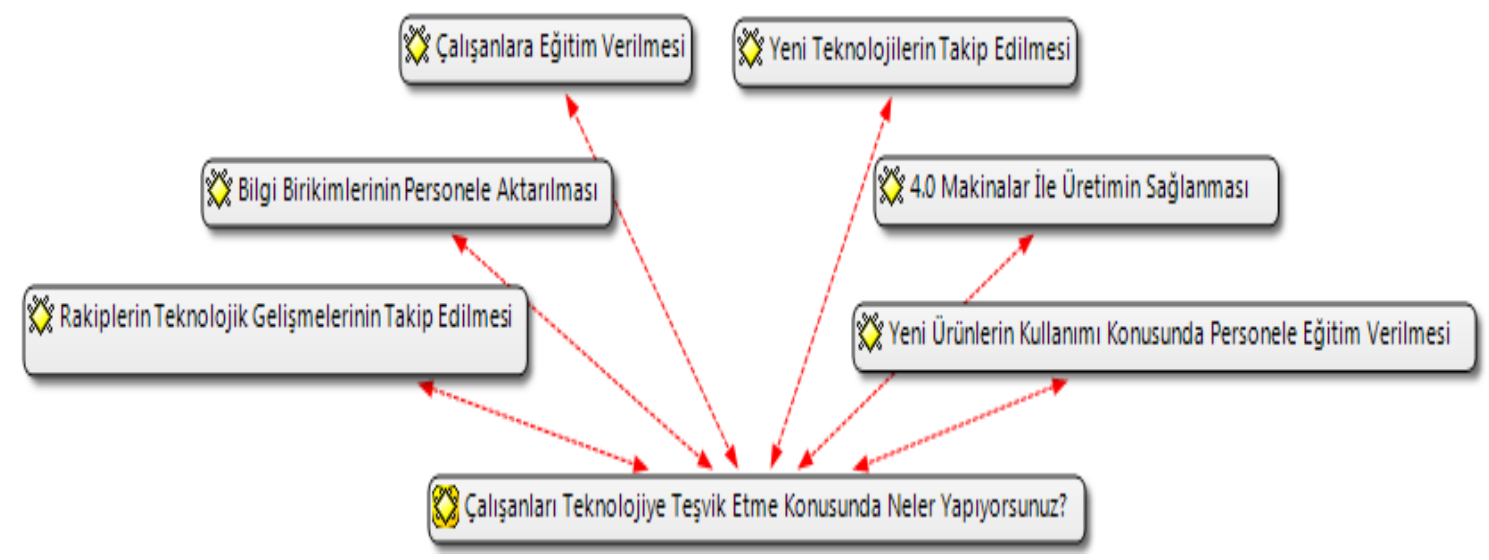

Şekil 7. Katılımcıların Çalışanları Teknolojiye Teşvik Etme Konusunda Neler Yapıyorsunuz?” Sorusuna Yönelik Verdikleri Cevaplar

Katılımcılar bu konuda rakip firmaların teknolojik gelişmelerinin takip edilmesi, bilgi birikimlerinin personele aktarılması, çalışanlara eğitim verilmesi, yeni teknolojilerin takip edilmesi, 4.0 makinalar ile üretim yapılması ve yeni ürünlerin kullanımı konusunda personellere eğitimlerin verilmesi ile çalışanları teşvik ettiklerini ifade etmişlerdir.

Yönetim teknoloji kullanımı noktasında bilgisini personele aktarıyor. Gerekli katılım sağlaniyor (K2).

Üst teknolojide hala değiliz. Çalışanların yetersizliği nedeniyle sorunlar oluşuyor. Fakat ileride personel olmadan müşterinin kendi yakıtını kendisi alabileceği sistemler gelecek (K3).

İşimizin parçası olarak yeni aletler, makinalar aldığımızda bunların kullanımı konusunda çalışanlara eğitim verilmektedir (K18).

Soru 10: “Ar-Ge Birimi Hakkında Ne Düşünüyorsunuz? Yönetim Ar-Ge Konusunda Ne Düşünüyor? Ar-Ge İçin Bütçe Ayırıyor Musunuz?”

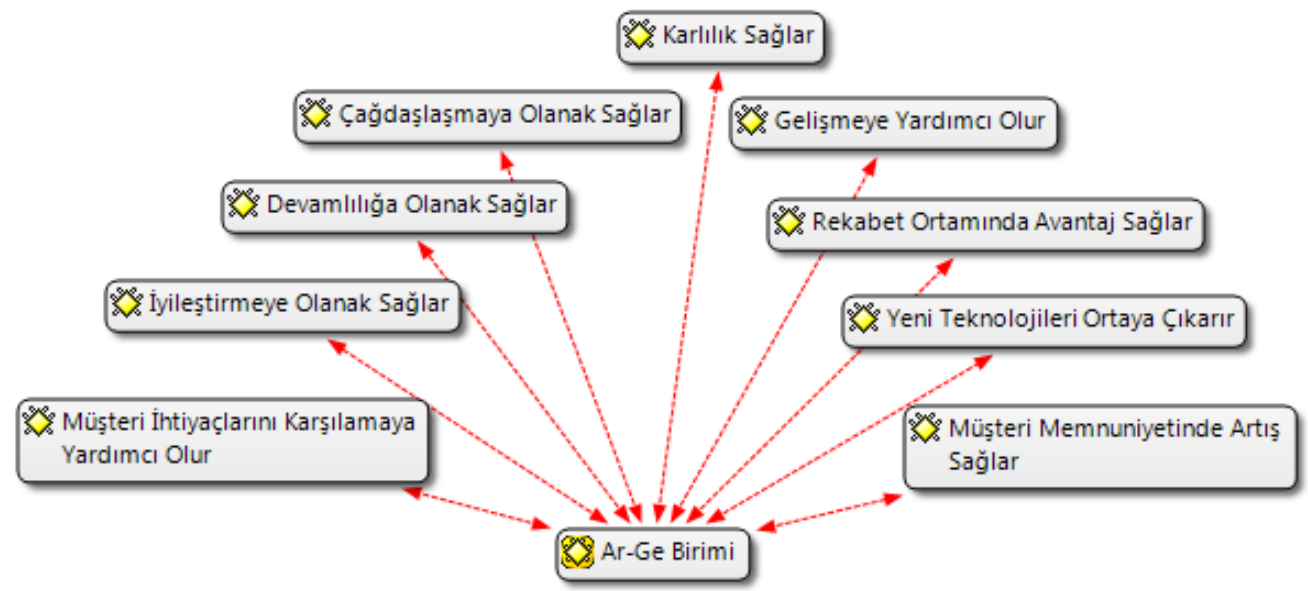

Şekil 8. Katılımcıların Ar-Ge Birimi Hakkında Düşüncelerine Yönelik Verilen Cevaplar

Katılımcıların 12'si Ar-Ge birimleri olmadığını Ar-Ge ile ilgili bir çalışmaları olmadığını ifade ederken, 8'i işletmelerinde Ar-Ge birimi olduğunu veya Ar-Ge ile ilgili çalışmalar yürüttüklerini ifade etmişlerdir. Ayrıca katılımcılar Ar-Ge'nin müşteri ihtiyaçlarını karşılamaya yardımcı olduğunu, iyileştirmeye, çağdaşlaşmaya olanak sağladığını, rekabet ortamında avantaj ve karlılık sağladığını, gelişmeye yardımcı olduğunu, yeni teknolojileri ortaya çıkardığını dile getirmişlerdir. 
Firmamız için Ar-Ge olmazsa olmazdır. Çünkü Ar-Ge yeni teknolojileri bulmada önemli (K2).

Bayiliklerini yapmış olduğumuz firmaların Ar-Ge çalı̧̧malarından yararlanıyoruz. Ar-Ge nin öneminin ne kadar büyük olduğunun hepimiz farkındayız. Karlılık, getiri ve müssteri memnuniyeti sağlamaktadır (K4).

Ar-Ge önemli. Bunun için çalı̧̧an arkadaşlarımı var. Ar-Ge diye bir bölümümüz yok. Genellikle ürünlerimizi nasıl geliş̧tiririz, özelliklerini iyileştiririz. Bununla ilgili çalışıyorlar. Bunun için ekstra bir bütçe ayırmıyoruz (K10).

Soru 11: "Üst Yönetim Gelecekle İlgili Ne Gibi Stratejik Planlamalar Yapıyor? Bu Planlar İçesinde Teknolojik Gelişmelerin Yeri Hakkında Neler Düşünüyorsunuz?”

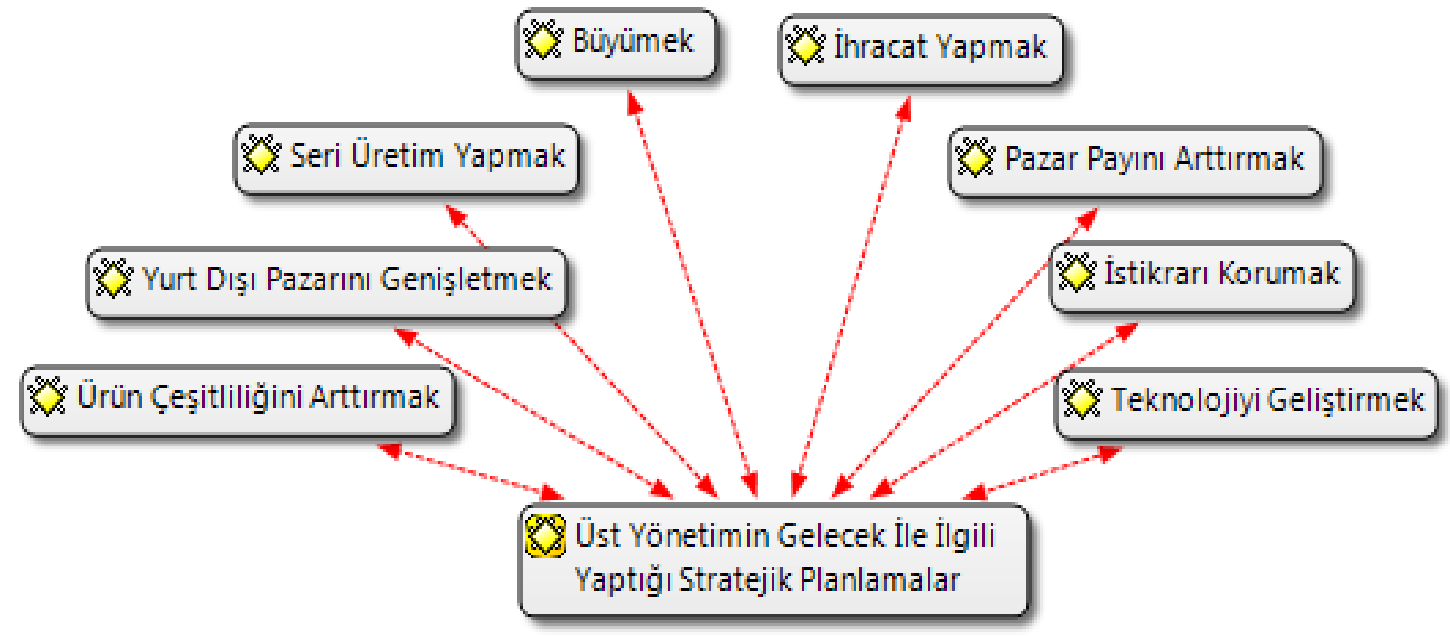

Şekil 9. Üst Yönetimin Gelecek ile İlgili Yaptığı Stratejik Planlamalara Yönelik Verilen

Cevaplar

Katılımcıların verdiği cevaplar doğrultusunda üst yönetimin gelecek ile ilgili ürün çeşitliliğini arttırmak, yurt dışı pazar payını genişletmek, seri üretim yapmak, büyümek, ihracat yapmak, pazar payını arttırmak, istikrarını korumak ve teknolojiyi geliştirmek gibi stratejik planlamaları olduğu görülmektedir.

Her üst yönetimin yaptığ gibi şirketimizde stratejik planlama yapmaktaylz. Teknolojik gelişmeler önceliklerimiz arasinda bulunmakta (K1).

Üst yönetim gelecekle ile ilgili stratejik planlama yapıyor. Teknolojik gelişmelerin alt yapısı ile ilgili çalışmalar sürmektedir (K2).

Soru 12: "İşletmenizin Hukuki Yapısı Nedir? İşletmeniz Aile İşletmesi Mi? Karaları Kimler Alıyor? Profesyonel Yöneticiniz Var Mı?”

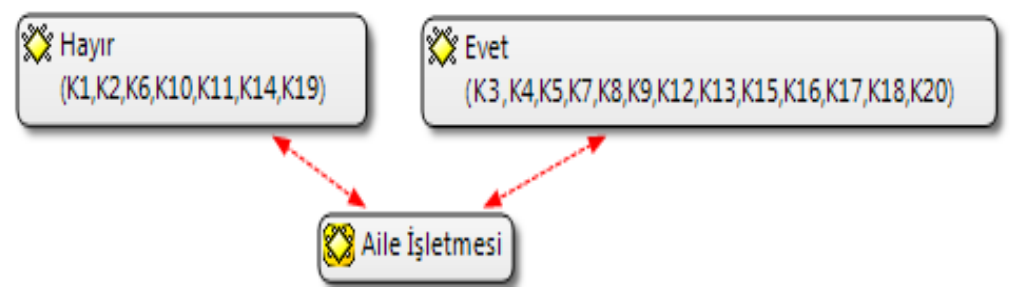

Şekil 10. Katılımcıların “İşletmeniz Aile İşletmesi Mi?” Sorusuna Yönelik Verdikleri Cevaplar 


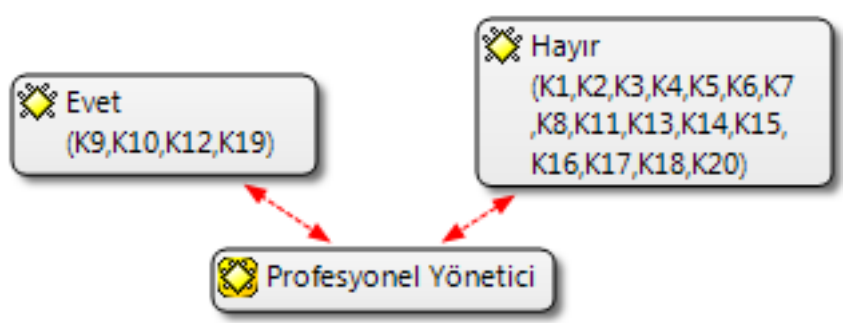

Şekil 11. Katılımcıların “Profesyonel Yöneticiniz Var Mı?” Sorusuna Verdikleri Cevaplar

Katılımcı işletmelerin 7'sinin aile işletmesi olmadığı, 13'ünün ise aile işletmesi olduğu görülmektedir. Ayrıca bu işletmelerin 4'ü profesyonel yöneticiye sahipdir.

Aile işletmesi değiliz. Karar alınması üst yöneticiler tarafindan yapılmakta. Yöneticilerimiz profesyonel değiller fakat iş konusunda iyiler (K1).

Işletmemiz aile şirketidir. Ve kurumsal bir yapıdadır. Görev yerleri farkl olan aile bireyleri ve yöneticilerin kararına saygı vardır (K4).

Aile işletmesi. Karaları aile üyeler veriyor. Profesyonel yöneticimiz var. O genelde işyerinin düzeni ve çalışanlar ile ilgileniyor. Işsletmede kararlar aile bireyleri tarafinda alınıyor (K9).

Soru 13: "Dış Kaynaklardan Faydalanıyor Musunuz? Örneğin Başka Firmalardan Teknoloji Transferi Yapıyor Muşununuz? Teknolojik İşlerinizi Diğer Firmalara Yaptırıyor Musunuz?"

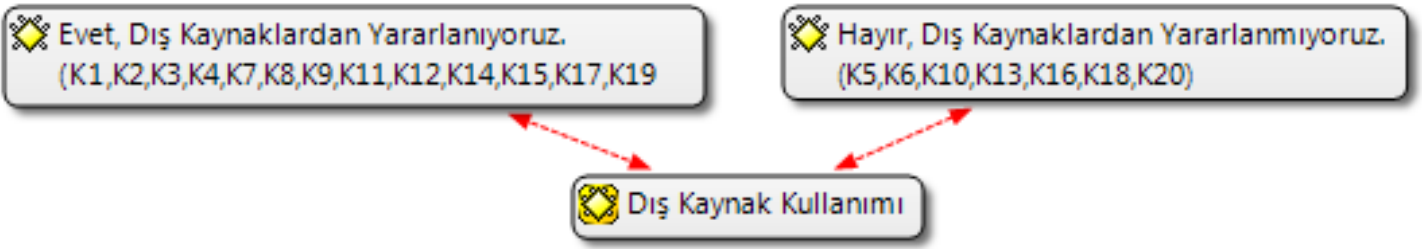

Şekil 12. Katılımcıların “Dış Kaynaklardan Faydalanıyor Musunuz?” Sorusuna Yönelik Verdikleri Cevaplar

Katılımcılardan 13 kişi dış kaynaklardan yararlandıklarını söylemişlerdir.

Bazen kullandığımız programlarla ilgili dış kaynaklardan destek alıyoruz (K1).

Dış kaynaklardan faydalanıyoruz. Karşılıklı teknoloji transferi noktasında çalışmalarımız bulunuyor. Bu sayede rekabet gücümüz arlyor (K2).

\section{Sonuç, Tartışma ve Öneriler}

Ülke ekonomileri için önemli bir yere sahip olan KOBİ'ler üretime ve istihdama sağladıkları katkılar nedeniyle desteklenmekte ve sayılarının artması istenmektedir. Endüstri 4.0 dediğimiz dördüncü sanayi devrimi döneminde teknolojinin hızla gelişmesi, KOBİ'lerin teknolojiyi takip etmesini kaçınılmaz hale getirmiştir. Bu nedenle KOBİ'lerin teknoloji kullanımının araştırılması önemli görülmüştür. Bu çalışmada, KOBİ'lerin teknoloji kullanımı konusunda yaşadıkları iktisadi ve yönetsel sorunların ortaya konulması amaçlanmıştır. Yapılan araştırma neticesinde KOBI'lerin mevcut durumu ortaya konularak, çözüm önerileri sunulmaya çalışılmıştır.

Araştırma neticesinde, KOBİ'lerin çoğunluğunun teknolojinin hızla geliştiğini ve imkânları dâhilinde teknolojik gelişmelere ayak uydurduklarını dile getirdikleri görülmüştür. KOBİ'ler rakipleri ile kendilerini teknoloji konusunda kıyasladıklarında ise, bir kısmı kendi firmasını rakiplerinden üstün görüyorken büyük bir kısmı bu konuda rakipleri ile kendi firmalarının başa baş gittiklerini belirtmişlerdir. KOBI'ler teknolojik gelişmelerin; hızlı sevkiyata olanak sağladığı, ihracata imkân tanıdığı, ürün farklılığında avantaj sağladığı, müşteri isteğini karşıladığı, ihtiyaçları daha güvenli ve 
hızlı bir şekilde karşıladığı, kaliteyi arttırdığı, hızlı üretime olanak sağladığı, müşterilere ve tedarikçilere ulaşımı hızlandırdığı, rekabet gücünü arttırdığını ifade etmişlerdir.

KOBİ'ler araştırma sonucunda, teknolojik sorunlarını diğer sorunları ile karşılaştırdıklarında ise, alt yapı eksikliğii, hammadde tedariki, ihracat ve pazar sorunu, ekonomik kriz, ek maliyetler, yapısal ve bürokratik sorunlar, yüksek vergiler, yetersiz alt yapı ağ 1 ve kalifiye eleman yetersizliği gibi sorunların teknolojik gelişim sorununun önüne geçtiği görülmektedir. KOBİlerin teknolojileri kullanırken yaşadıkları problemlerin ise; hammadde tedariki, kalifiye eleman sıkıntısı, teknik problemler, üretim sıkıntısı, personel eksikliği, ekonomik problemler, maliyetli teknoloji ve teknolojik altyapı eksikliği gibi problemlerle karşılaştıkları görülmüştür. Ayrıca katılımcıların çoğu karşılaştıkları sıkıntıların içerisine ekonomik problemleri de eklemişlerdir. KOBİ'lerin bir kısmının teşviklerden haberdar oldukları, teşviklerden haberdar olan katılımcıların bazılarının teşviklerden faydalandıkları görülmüştür. Ayrıca katılımcıların bir kısmı teşviklerden haberdar olmadıklarını ve hatta bu konu hakkında hiçbir bilgisinin olmadığını ifade etmiştir. Yine araştırma bulgularına göre: KOBİ'lerin çoğunluğunun kalifiye eleman konusunda sıkıntı yaşadıkları, teknolojiye hâkim, sadece teoride değil aynı zamanda uygulamada da başarılı olabilen elemanlara ihtiyaç olduğunu vurgulamışlardır. Gökalp, Ada ve Demirhan (2006) yaptıkları çalışmada bizim bulgularımıza paralel olarak, işletmelerin bilgi teknolojilerini kullanmalarının maliyetleri artırdığını, bilgi teknolojileri yatırımlarının maliyetinin yüksekliğini ve nitelikli personel eksikliğini tespit etmişlerdir. Benzer şekilde Gedik (2017) yaptığ çalışmada, bizim çalışmamızı destekler şekilde nitelikli eleman, teknik bilgi eksikliği, devlet desteğinin yetersiz olması konularını tespit etmiş bizim çalışmamızdan farklı olarak sanal ortamdaki güvenlik sorunu, tanıtım ve bilgilendirme eksikliği gibi sıkıntıların olduğu bulunmuştur. Avşar vd. (2018) ise çalışmalarında, araştırmamızla paralel olarak nitelikli personel sıkıntısının yaşandığını, işletmelerin bir kısmının rekabette teknolojilerini yeterli görmedikleri sonucuna ulaşılmıştır.

Araştırmanın bir diğer sonucu ise, katılımcılar üst yönetimin, rakip firmaların teknolojik gelişmelerinin takip edilmesi, bilgi birikimlerinin personele aktarılması, çalışanlara eğitim verilmesi, yeni teknolojilerin takip edilmesi, 4.0 makinalar ile üretim yapılması ve yeni ürünlerin kullanımı konusunda personellere eğitimlerin verilmesi ile çalışanları teşvik ettiklerini ifade etmişlerdir. Yine araştırmaya dahil olan çoğu KOBİ'nin Ar-Ge biriminin olmadığı, olan firmaların ise, Ar-Ge'nin müşteri ihtiyaçlarını karşılamaya yardımcı olduğunu, yeni teknolojileri ortaya çıkardığını ve müşteri memnuniyetinde artış sağladığını dile getirmişlerdir. Üst yönetimin gelecekle ilgili ne gibi stratejik planlamaları olduğu sorusu neticesinde, üst yönetimin gelecek ile ilgili ürün çeşitliliğini arttırmak, yurt dışı pazar payını genişletmek, seri üretim yapmak, büyümek, ihracat yapmak, pazar payını arttırmak, istikrarını korumak ve teknolojiyi geliştirmek gibi stratejik planlamalarının olduğu görülmektedir. Avşar, Erkek ve Erkek (2018) ise çalışmalarında, işletmelerin çoğunluğunun Ar-Ge ve inovasyon teşviklerini yetersiz bulduğunu, Varol ve Kaygısız (2018) ise bizim çalışmamızdan farklı olarak işletmelerin, çalışan sayısı ve faaliyet süreleri arttıkça teknoloji kullanım oranlarında ve inovatif çalışmalar gerçekleştirme kapasitelerinin arttığını, üretimde yeni malzeme kullanımından kaçındıklarını tespit etmişlerdir. Marques, Acosta ve Merigo (2015) yaptıkları çalışmada, teknolojinin KOBI'lerde web bilgi alışverişinde etkili olmadığı, bilgi teknolojisini bilen personelin olmasının internet teknolojilerinde önemli olduğu ve insan kaynaklarının önemli olduğu sonuçlarına ulaşmışlardır. Mittal, Khan, Romero ve Wuest (2018) çalışmalarında, yeni teknolojilerin ve örgüt kültürünün oluşturulmasının daha fazla kaynak gerektirebileceğini ve zaman alabileceğini, endüstri 4.0 bağlamında KOBİ'lerin teknolojik gelişmeler için bir danışmana ihtiyaç duyabileceğini ve KOBİ'lerin yönetsel açıdan vizyon sahibi yöneticiler yardımıyla başarılı olacağı sonuçlarına ulaşmışlardır.

Bu sonuçlar doğrultusunda araştırmaya katılan KOBİ'lerin, teknolojinin önemini bildikleri ve kendilerine avantaj sağlayacağının farkında oldukları görülmüştür. Buna rağmen teknolojiyi elde etme konusunda ekonomik koşullarda sıkıntı yaşadıkları, kalifiye eleman bulmakta zorlandıkları görülmüştür. Verilen teşvikler konusunda KOBİ'lerin büyük çoğunluğunun eksik bilgiye sahip olduğu yada haberdar olmadığı görülmüştür. KOBİ'ler de üst yönetimin teknolojinin öneminin bilincinde olduğu bu konuda çalışanları eğitmeye çalıştı̆̆ görülmüştür. Yine araştırma sonuçlarına göre çoğu işletmenin aile işletmesi olduğu ve profesyonel yöneticisinin olmadığı sonuçlarına ulaşılmıştır. 
Araştırmanın sadece Kırşehir ilinde faaliyet gösteren KOBİ'leri kapsaması araştırmanın bir sınırlılığı olarak söylenilebilir. Ayrıca araştırmaya katılan işletmelerin sayısı ve faaliyet gösterdiği sektörlerde araştırmanın bir sınırlılığı olarak görülmektedir. Araştırma neticesinde KOBI’lere;

- $\quad$ Teknolojiyi elde etmek ihtiyaç duyulan finansal kaynağı artırmaya çalışmaları,

- $\quad$ Kalifiye eleman problemlerini çözmek için üniversiteler ve diğer meslek örgütleriyle işbirliği yapmaları, teşvikler konusunda gerekli bilgiyi elde edebilmek için iyi araştırma yapmalar1,

- $\quad$ Ar-Ge birimlerinin oluşturulmasının öneminin bilinmesi ve en kısa zamanda Ar-ge birimlerinin kurulmas1,

- $\quad$ Yönetim kademesinde profesyonel yöneticilere yer verilmesi

- $\quad$ Özellikle Endüstri 4.0 kapsamındaki gelişmeleri takip ederek teknolojik gelişmelerin öneminin dikkate alınması ve yönetimin bu hususta hassas olması önerilmektedir.

Bu araştırma ile KOBİ'lerin teknoloji konusunda yaşadıkları iktisadi ve yönetsel problemler tespit edilmeye çalışılmıştır. Bundan sonraki çalışmalarda ekonomiler için önemi çok büyük olan KOBI'lerin başka bölgelerde teknoloji konusundaki problemleri araştırmacılar tarafindan incelenebilir. KOBİ'lerin yaşadığ diğer problemler; kalifiye iş gücü, Ar-Ge, teşviklerden haberdar olma ve kullanımı, profesyonel yönetilip yönetilemedikleri gibi konularında araştırma konusu yapılabileceği araştırmacılara önerilir.

$\mathrm{Bu}$ çalş̧mada, ülke ekonomilerinin lokomotifi niteliğindeki KOBİ'lerin günümüzde teknolojiyi elde etme konusundaki iktisadi ve yönetsel durumları ortaya konularak ilgili literatüre katk1 sağlamak amaçlanmıştır. KOBİ'lere problemlerinin çözümü konusunda öneriler sunulmuştur.

\section{Yazarların Katkı Oranı}

Çalışma tek yazarlı olduğu için yazarın katkı oranı \%100'dür.

\section{Çıkar Çatışması}

Bu çalışmada çıkar çatışması oluşturacak bir husus yoktur.

\section{Kaynaklar}

Adjouman, D. (2014). Factors influencing SMEs in adoption and use of technology in cote d'Ivoire diabate. International Journal of Business and Management, 9(8), 182.

Agwu, O. M. (2014). Issues, challengesand prospectsof Small and Medium Scale Enterprises (SMEs) in Port-Harcourt City, Nigeria. European Journal of Sustainable Development, 3(1), 101-114.

Akdede, S. H. ve Turan, A. H. (2008). Bilişim sistemlerinin KOBI'lerin performansına etkileri: Kaynak Temelli Yaklaşım ile Denizli ilinde ampirik bir uygulama. Ankara Üniversitesi SBF Dergisi, 63(4), 6-8.

Akderujjaman, S. M. (2010). Problems and prospects of SMEs loan management: A study on Mercantile Bank Limited. Journal of Business and Technology, 5(2), 38- 52.

Altay, H. ve İlban, M. O. (2007). Balıkesir Organize Sanayi Bölgesi KOBİ yöneticilerinin organizasyon algıları üzerine bir araştırma. Anadolu Üniversitesi Sosyal Bilimler Dergisi, 7(1), 112.

Apan, M. ve İslamoğlu, M. (2014). KOBİ'lerde finans yönetimi. International Journal and Science Culture and Sport, 2(1), 208- 218. 
Avşar, B., Erkek, S. ve Erkek, A. (2018). 2005-2015 Yılları arasında Türkiye'de uygulanan Ar-Ge ve inovasyon politikalarının KOBİ'ler üzerindeki etkisi: Konya tarım alet ve makineleri imalat sektörü örneği. Selçuk Üniversitesi Sosyal Bilimler Meslek Yüksekokulu Dergisi, 21(1), 1-17.

Aydoğan, E. ve Altuğ, M. (2006). Küçük ve Orta Ölçekli İşletmelerin (KOBİ) rekabet gücünün arttırılmasında ileri yönetim teknolojilerinin rolü: Makine ve imalat sektörüne yönelik bir uygulama. Selçuk Üniversitesi Sosyal Bilimler Enstitüsü Dergisi, 16, 87-110.

Aydoğan, E. ve Semiz, S. (2004). İşletmelerde teknoloji yönetimi bağlamında ileri üretim teknolojileri ve otomotiv sektöründe bir uygulama. Selçuk Üniversitesi Sosyal Bilimler Enstitüsü Dergisi, $11,116$.

Creswell, J. W. (2013). Research design: Qualitative, quantitative, and mixed methods approaches. New York: Sage Publications.

Çetin, H. C. (2007). Türkiye'de küçük ve orta ölçekli işletmelerin finansman sorunları ve bu sorunlara yönelik politikalar (Kredi Politikaları). Yüksek Lisans Tezi, İstanbul Üniversitesi Sosyal Bilimler Enstitüsü, İktisat Anabilim Dalı, İstanbul.

Eğmir, T. R. ve Hazman, G. G. (2017). KOBİ'lere sağlanan teşvikler ve KOBİ'lerin vergi algısı ilişkisi: Afyonkarahisar örneği. Çankırı Karatekin Üniversitesi İktisadi ve İdari Bilimler Fakültesi Dergisi, 7(2), 225-246.

Gedik, H. (2017). Konya Organize Sanayi Bölgesi'ndeki KOBİ'lerin e-pazarlama uygulamaları. Klrklareli Üniversitesi İktisadi ve İdari Bilimler Fakültesi Dergisi, 6(5), 129-149.

Gökalp, F., Ada, E. ve Demirhan, D. (2006). Gelişen bilgi teknolojilerinin KOBİ'lere etkisi. Gazi Üniversitesi İktisadi ve İdari Bilimler Fakültesi Dergisi, 8(2), 117-136.

Göker, A. (2001). KOBİler ve teknoloji sorunu. www.inovasyon.org/images/makaleler/cbt/AYK. 15.11.2020 tarihinde edinilmiştir.

Gürler, İ. ve Güler, E. (2009). Üretim süreçlerinde kullanılan teknoloji için seçim kriterleri ve süreçlerin yeniden yapılandırılmasında simülasyon uygulaması. Ege Akademik Bakış, 9(2), 623-635.

Kaygın, C. Y. ve İkinci, A. (2019). Küçük ve Orta Büyüklükdeki İşletmelerin finansal sorunlarına işletme sahiplerinin bakış açısı: Kars ili örneği. Uluslararası Toplum Araştırmaları Dergisi, 13(19), 1759.

Küçük ve Orta Büyüklükdeki İşletmelerde Stratejisi Eylem Plan1. (2015). Küçük ve orta büyüklükdeki işletmelerde stratejisi eylem planı. https://www.kosgeb.gov.tr.adresinden 17.11.2020 tarihinde erişilmiş̧tir.

Kutlu, A. H. ve Demirci, N. S. (2007, 7-8 Aral1k). KOBI'lerin finansal sorunları ve çözüm önerileri. KOBI'ler ve Verimlilik Kongresi, İstanbul Kültür Üniversitesi, İstanbul. https://www.researchgate.net/profile/NsavasDemirci/ adresinden $15.10 \quad 2020$ tarihinde erişilmiştir.

Marquez, D. P., Acosta, P. S. and Merigo, J. M. (2015). Analyzing the effects of technological, organizational and competition factors on Web knowledge exchange in SMEs. Telematics and Informatics, 32(2015), 23-32. 
Mittal, S., Khan, M. A., Romero, D. and Wuest, T. (2018). A critical review of smart manufacturing \& Industry 4.0 maturity models: Implications for small and medium-sized enterprises (SMEs). Journal of Manufacturing Systems, 49, 194-214.

Özdemir, H. M. (2010). Küçük ve Orta Ölçekli İşletmelerde teknoloji yönetimi ve ileri üretim teknolojileri kullanımı: Makine imalat sektöründe bir uygulama. Yüksek Lisans Tezi, Gazi Üniversitesi, Fen Bilimleri Enstitüsü, Ankara.

Özgener, Ş. (2003). Büyüme sürecindeki KOBİlerin yönetim ve organizasyon sorunları: Nevşehir UN Sanayii Örneği. Erciyes Üniversitesi İktisadi İdari Bilimler Dergisi, 20,137-161.

Öztürk, O. (2019). Firmalar için stratejik bir seçenek olarak bă̆ımlılı: Kaynak Bă̆ımlıll̆̆g Kuramına bir katkl. Doktora Tezi, Sakarya Üniversitesi, İşletme Enstitüsü, Sakarya.

Pfeffer, J. and Salancik, G. R. (2003). The external control of organizations: A resource dependence perspective. California: Tanford Business Press.

Silverman, D. (2001). Interpreting qualitative data: Methods for analysing talk, text and interaction. London: SAGE Publication.

Şahin, D. B. ve Özüdoğru, H. (2019). KOBİ'lerde üretim pazarlama sorunları: Ostim Örneği. Üçünsü Sektör Sosyal Ekonomi Dergisi, 54(1), 320-333.

Şenel, A. ve Gençoğlu, S. (2003). Küreselleşen dünyada teknoloji eğitimi. Gazi Üniversitesi Endüstriyel Sanatlar Eğitim Fakültesi Dergisi, 11(12), 45-65.

Tekin, M., Güleş, H. K. ve Öğ̈̈t, A. (2003). Değiş̧im çağında teknoloji yönetimi. Ankara: Nobel Yayınevi.

Turan, A. H. (2007). Kaynak Temelli Yaklaşım bağlamında bilişsim sistemlerinin KOBI'lerin performansina etkileri: Denizli ilinde ampirik bir çalışma. Yüksek Lisans Tezi, Adnan Menderes Üniversitesi Sosyal Bilimler Enstitüsü, İşletme Ana Bilim Dalı, Aydın.

Türkan, Y. (2011). KOBI'lerin finansman sorunları bu sorunların çözümünde KOBİ borsaları ve bir araştırma. Yüksek Lisans Tezi, Atatürk Üniversitesi, Sosyal Bilimler Enstitüsü, Erzurum.

Ülgen, H. ve Mirze, S. K. (2010). İsletmelerde stratejik yönetim. İstanbul: Beta Yayınları.

Varol, A. ve Kaygısız, E. G. (2018). KOBI’lerde teknoloji kullanımı: Giresun ili örneği. Karadeniz Sosyal Bilimler Dergisi, 10(19), 535-552.

Yelkikalan, N. ve Ener, M. (2001, 18-21 Ekim). KOBİlerin Avrupa Birliğine entegrasyon sürecinde karşılaştıkları teknolojik sorunlar. I. Orta Anadolu Kongresi, Nevşehir. https://core.ac.uk/download/pdf/47254379.pdf, adresinden 11.10.2020 tarihinde erişilmiştir.

Yıldırım, A. ve Şimşek, H. (2011). Sosyal bilimlerde nitel araştırma yöntemleri. Ankara: Seçkin Yayıncilik. 


\section{Extended Abstract}

\section{Introduction}

In today's economic environment, it is very difficult for businesses to survive and compete with the effect of free market economy and globalization. Apart from the economies of the country, most of the enterprises are trying to become multinational and dominate the world market. In addition to large enterprises in developed countries, Small and Medium Sized Enterprises (SMEs) are also the locomotive of the economy. Among the developing countries, SMEs are very important economically and are constantly supported and their numbers are aimed to be increased, especially due to their contribution to employment, production and the country's economy.

SMEs, which are of great importance for the economies of the country and constitute the most enterprises in number, have to follow the developing technology and provide a sustainable competitive advantage. In order for the technological infrastructure to be planned and put into practice, the management must have the necessary knowledge and skills in this regard. Therefore, if the managers are professional or receive the necessary training, managerial problems will be reduced. In the economic sense, it is not easy for SMEs to reach the financial resources they need and solve the economic problems they face in technology investments as in every field. For this reason, it is important to investigate the managerial and economic problems experienced by SMEs in technology and to offer solutions.

The purpose of this study is to reveal the processes of accessing and using technology by SMEs, to determine whether they are able to follow technological developments by trying to measure the knowledge and experience of managers in technology, and to try to reveal the economic problems they face in obtaining technology. In the research, the study topics were discussed and explained conceptually. Then, using the qualitative research design, various questions were asked to the business managers, and as a result of the answers, various situation determinations were made and it was aimed to offer solutions to the problems encountered. There are many problems faced by SMEs, which have a very important place in the economies of developing countries. The fact that these problems are put forward by the researchers will also shed light on the measures to be taken. The study was deemed important as it is thought to contribute to revealing the problems of SMEs. The aim of the research is to reveal the economic and managerial problems SMEs experience in obtaining the rapidly developing technology today. To offer solutions to the problems of SMEs in the light of the findings obtained. In line with the purpose of this research, the main question it seeks to answer is: "What are the economic and managerial problems SMEs have about using technology? constitute expression.

This research is a case study conducted in order to reveal the economic and managerial problems of SMEs regarding the use of technology and data are collected with a qualitative method. The purpose of the study is to identify the problems of SMEs by collecting detailed and in-depth information about the current problems and situations experienced by SMEs regarding the use of technology, by describing a situation or by revealing themes of the situation (Creswell, 2013). In the research, firstly, the research question form was created in line with the expert opinions. In accordance with the research problem, the questions are questions that reveal the economic and managerial problems faced by enterprises in the use of technology. Research data were collected by interview method. Categories were created by analyzing the data obtained as a result of the research in an appropriate statistical program. Then, content analysis was made in line with the data. Content analysis is one of the commonly used methods among qualitative data analysis types. In content analysis, categories related to the research subject are created (Silverman, 2001), and the results found on the research subject are reported. In the research, research data were collected by reaching 20 SMEs operating in Kırşehir. It is stated that 5 to 20 samples may be sufficient in qualitative studies (Creswell, 2013). 


\section{Method}

The research data were collected by interview method. While collecting the research data, the participants were determined and the content of the interview and the time to spare were given to the participants. Data were collected through face-to-face interviews with 20 participants who accepted the interview, and voice recordings were taken. In order to analyze the research data, the data were first arranged to be ready for analysis. Then, the data were subjected to the Atlas: ti program and encoded. With the content analysis one of the qualitative research methods, the findings were interpreted and associated with the literature and comparisons were made.

\section{Findings}

As a result of the research, it was seen that most of the SMEs stated that technology is developing rapidly and that they keep up with technological developments within their possibilities. When SMEs compare themselves with their competitors in terms of technology, while some consider their company superior to their competitors, most of them stated that their rivals and their companies go hand in hand with this. SMEs of technological developments; It enables fast shipping, enables export, provides advantage in product diversity, meets customer demands, meets needs more safely and quickly, enables rapid production, accelerates access to customers and suppliers, increases competitiveness, helps eliminate deficiencies, They stated that it meets the innovations and makes the business the focus of preference.

\section{Conclusion, Discussion and Recommendations}

As a result of the research, when SMEs compare their technological problems with other problems, problems such as lack of infrastructure, raw material supply, export and market problem, economic crisis, additional costs, structural and bureaucratic problems, high taxes, inadequate infrastructure network and inadequacy of qualified personnel. it is seen that the technological development problem has been prevented. The problems SMEs experience while using technologies are; It was observed that they faced problems such as raw material supply, qualified personnel shortage, technical problems, production shortage, lack of personnel, economic problems, costly technology and lack of technological infrastructure. In addition, most of the participants added economic problems to the difficulties they faced. When asked about the information of SMEs on incentives, it was observed that some of them were aware of the incentives and some of the participants who were aware of the incentives benefited from the incentives.

It can be said as a limitation of the research that the research covers only SMEs operating in Kırşehir province. In addition, the number of enterprises participating in the research and the sectors in which they operate is seen as a limitation of the research. As a result of the research, to SMEs;

- Trying to increase the financial resources needed to acquire technology,

- Cooperating with universities and other professional organizations to solve qualified personnel problems, doing good research to obtain the necessary information about incentives, as possible,

- Recognizing the importance of establishing $R \& D$ units and establishing $R \& D$ units as soon

- Employing professional managers at the management level

In this study, it is aimed to contribute to the related literature by revealing the economic and managerial situations of SMEs, which are the locomotives of the country's economies, in obtaining technology in today's technology age. SMEs have been offered suggestions on the solution of their problems. 